University of Zurich

Department of Economics

Working Paper Series

ISSN 1664-7041 (print)

ISSN 1664-705X (online)

Working Paper No. 65

\title{
The French Great Depression: A Business Cycle Accounting Analysis
}

Slim Bridji

February 2012 


\title{
The French Great Depression: A Business Cycle Accounting Analysis
}

\author{
Slim Bridji*
}

February 24, 2012

\begin{abstract}
Using the business cycle accounting framework [Chari V., P. Kehoe and E. McGrattan 2007. Business Cycle Accounting. Econometrica 75, 781-836.], this paper sheds new light on the French Great Depression. Frictions that reduce the efficiency with which factor inputs are used (efficiency wedge) were the primary factor in the economic downturn. The decline in consumption can be attributed to distortions in the Euler equation (investment wedge). In addition, frictions creating a gap between the marginal rate of substitution and the marginal product of labor (labor wedge) contributed to the slowdown of the economy after 1936. This drop in the efficiency wedge might have resulted from financial frictions and tariff policies, whereas the investment wedge might have been caused by financial frictions due to agency costs. A potential explanation for the decline of the labor wedge after 1936 is institutional changes in the labor market.
\end{abstract}

Keywords: Business Cycle Accounting; French Economy; Great Depression. JEL Classifications: E32, N14, N44.

\footnotetext{
*University of Zurich, Department of Economics. Email: slim.bridji@econ.uzh.ch. I am indebted to Fabien Tripier for his helpful guidance and support. I thank Vincent Bignon, Claude Diebolt, Olivier Darné, Michel Juillard, Franck Portier, and Ulrich Woitek for their helpful comments. I would also like to thank participants of the 18th Annual Meeting of the Society for Economic Dynamics (Prague, June 2007), the 22nd Annual Conference of the Irish Economic Association (Westport, April 2008), the 13rd Spring Meeting of Young Economists (Lille, April 2008), a seminar at the University of Zurich (April 2008) and the 8th Conference of the European Historical Economic Society (Geneva, September 2009). All remaining errors are mine.
} 


\section{Introduction}

During the Great Depression, French output dropped by approximately 21 percent below the trend in 1939. Consumption, hours worked, and investment also collapsed, showing no sign of recovery until 1936. There are three competing explanations for this period of economic downturn. Observing that French prices increased relative to foreign prices as a result of the devaluation of the pound and dollar, Sauvy (1984) claimed that France sank deeply into a depression because the country used deflation route rather than devaluation to return prices to competitive levels.

A second explanation claims that the worldwide Great Depression was caused by a collapse of the global money supply caused by the malfunctioning of the gold standard (e.g., Eichengreen \& Sachs, 1985). Output and prices declined more sharply in countries that remained on gold until 1935 or 1936, such as France, when compared to countries that abandoned the gold standard in 1931. The slow adjustment of nominal wages to changes in prices is the conventional explanation of the non-neutrality of this monetary contraction.

Yet another explanation was offered by Lacoue-Labarthe (2005), who asserted that France experienced several bank runs in the early 1930s that might had been an important factor in the economic crisis. The banks that went bankrupt were primarily the most solvent ones. Interestingly, several other countries were also hit by banking crises in the early 1930s, including the U.S., Germany, Austria, and Hungary (see Friedman \& Schwartz, 1963; Schnabel, 2004, 2009). Although the traditional view is that the consequences of bank runs in France were not as important as in other countries, it is worth keeping this interpretation in mind. This paper aims to use the Business Cycle Accounting (BCA) method, developed by Chari et al. (2007) (CKM), to assess which of the explanations provided by the literature is relevant to France.

The BCA method relies on dynamic stochastic general equilibrium (DSGE) models. CKM emphasize that many models incorporating frictions can be reconstructed as neoclassical growth models with four shocks: a measure of technological change, a labor tax, an investment tax, and government expenditures. Within this framework, labeled the prototype model, CKM rename these shocks the efficiency wedge, labor wedge, investment wedge, and government consumption wedge. Frictions can also be modeled in detail, but here, in the prototype model, they are captured by wedges. The purpose of the BCA method is to identify which wedge or combination of wedges would help to understand the event under study. To address this issue, CKM propose an accounting exercise similar to the growth accounting procedure. Wedges measure the deviation of the fluctuations described by the neoclassical growth model from those observed in the data. Thus, one can generate series for the wedges and feed them back into the prototype model individually and in combination. Through this process, one can evaluate the contribution of the wedges to the observed fluctuations in the variables of interest.

The study closest to our work was conducted by Beaudry \& Portier (2002). They assessed the ability of the real business cycle (RBC) model to replicate the economic fluctuations in France during the 1930s. They found that the constructed shocks to technological change were not sufficient to explain the collapse of French economic activity. They also demonstrated that if one assumed that technological changes were embodied in capital, this shock would not even be necessary to account for the drop in output. Indeed, the fluctuations in labor and capital inputs were sufficient to replicate the decline in output. Beaudry \& Portier (2002) suggested that the French depression corresponded to a transition from one steady state to a lower one. This movement would be caused by institutional changes in the labor market - such as those led by the government of the Front Populaire in 1936 - and in the capital market.

The primary conclusions of our work can be summarized as follows. The efficiency wedge seems to be the main culprit of the French Great Depression, as it is sufficient to explain the 
observed fluctuations in output throughout the 1930s. The decline in the efficiency wedge may have resulted from financial frictions and/or tariff policies. The efficiency wedge is also able to explain most of the collapse in labor. It is also important to understand investment behavior during this period. However, the efficiency wedge contributes very little to the fluctuations in consumption.

The investment and labor wedges play a secondary role in the economic downturn. The investment wedge accounts for a non-negligible fraction of the decrease in consumption. That wedge might capture financial frictions caused by an agency problem (as in Carlstrom \& Fuerst, 1997). In turn, the contribution of the labor wedge is only significant after 1936, which can explain why the economy remained at a low level after 1936. We argue that the behavior of the labor wedge after 1936 may have been caused by the labor market reforms carried out by the government of the Front Populaire. The government consumption wedge accounts for almost none of the observed fluctuations in output, labor, investment, and consumption.

Those results contrast with the conclusions of Beaudry \& Portier (2002), who found that the shocks to technological change (efficiency wedge) were "neither sufficient nor necessary" to explain the French Great Depression. Interestingly, the BCA method seems to support the banking crisis hypothesis. Indeed, the French money multiplier, which can be taken as a measure of financial development, is highly correlated with the efficiency wedge during the 1930s.

The paper is organized as follows. Section 2 describes the business cycle accounting method. Section 3 discusses the French data over the 1896-1939 period. Section 4 presents the application of the BCA method to the French Great Depression. Section 5 concludes.

\section{The Business Cycle Accounting Approach}

The first idea advanced by $\mathrm{CKM}^{1}$ is that many detailed models incorporating frictions can be restated as neoclassical growth models including shocks to productivity, labor and investment taxes, and government spending. This variant of the RBC model, called the prototype model, can be interpreted as a reduced form model. The prototype model can be summarized by the following equilibrium equations ${ }^{2}$ :

$$
\begin{aligned}
& \gamma_{z} \gamma_{n} k_{t+1}=(1-\delta) k_{t}+x_{t} \\
& y_{t}=c_{t}+x_{t}+g_{t} \\
& y_{t}=k_{t}^{\theta}\left(z_{t} h_{t}\right)^{1-\theta} \\
& \left(1-\tau_{h, t}\right)(1-\theta) \frac{y_{t}}{h_{t}}=\psi \frac{c_{t}}{1-h_{t}} \\
& \left(1+\tau_{x, t}\right) \gamma_{z} \frac{1}{c_{t}}=\beta E_{t}\left\{\frac{\theta \frac{y_{t+1}}{k_{t+1}}+\left(1+\tau_{x, t+1}\right)(1-\delta)}{c_{t+1}}\right\}
\end{aligned}
$$

\footnotetext{
${ }^{1}$ CKM have applied the BCA method to the U.S. Great Depression. They find that the deterioration of the efficiency wedge over the 1929-1933 period accounts fairly well for the collapse of U.S. economic activity during that period; however, the decline of the labor wedge over the decade is largely responsible for the weak recovery of the U.S. economy. According to the authors, these results suggest that models with frictions that manifest themselves as an efficiency wedge, for instance, input financing problems (as originally suggested by Bernanke, 1983), and those that take the form of a labor wedge, such as workers' monopoly power (as recently stressed by Cole \& Ohanian, 2004; Christiano et al., 2003), are good candidates to understand the U.S. Great Depression. The BCA method has also been applied to the Belgium Great Depression by Pensieroso (2011). Note that the BCA method is designed for any business cycle fluctuation. This method has been applied to other historical crisis, such as the recession in the U.S. in the early 1980s (see Chari et al., 2007), in Japan in the 1990s lost decade (see Kobayashi \& Inaba, 2006), and in the U.K in the 1980s (see Kersting, 2008), as well as the crisis in Asia in 1997 (see Otsu, 2010) and the recessions in Latin America that took place between 1990 and 2006 (see Lama, 2011). For a critical discussion of the method, see Christiano \& Davis (2006).

${ }^{2}$ The prototype model is described in more detail in Appendix A.
} 
given the stochastic process followed by the vector of exogenous variables:

$$
S_{t+1}=P_{0}+P S_{t}+\epsilon_{t+1} \quad \epsilon_{t} \leadsto i . i . d .\left(0_{4}, V\right), S_{t}=\left(\log \left(z_{t}\right), \tau_{h, t}, \tau_{x, t}, g_{t}\right)^{\prime}
$$

Equation (1) represents the capital accumulation law, where $k_{t}$ stands for capital, $x_{t}$ for investment, $\gamma_{z}$ for the deterministic labor-augmenting technical progress gross growth rate, $\gamma_{n}$ for the population gross growth rate ${ }^{3}$, and $\delta$ for the capital depreciation rate. Equation (2) is the resource constraint of the economy, where $y_{t}$ denotes output, $c_{t}$ denotes private consumption, and $g_{t}$ denotes government consumption. Equation (3) represents the technology of production, where $z_{t}$ is a productivity shock, $h_{t}$ is labor (total hours worked), and $\theta$ is the capital income share parameter. Equation (4) is the equilibrium condition on labor. In equation (4), $\tau_{h, t}$ stands for the labor tax rate and $\psi$ is a preference for leisure parameter. Equation (5) is the stochastic intertemporal Euler equation, where $\tau_{x, t}$ stands for the investment tax rate and $\beta$ is the discount factor parameter. In equation (6), $P$ and $P_{0}$ are, respectively, a matrix and a vector of parameters, and $\epsilon_{t}$ is a vector of four independently and identically distributed perturbations with zero mean and a variance-covariance matrix $V$.

There are two ways to interpret the equilibrium conditions (1)-(5). On the one hand, one can say that they simply characterize a RBC model with a public sector, that is, a neoclassical growth model including shocks to technology, $z_{t}$, shocks to labor and investment taxes, $\tau_{h, t}, \tau_{x, t}$, and shocks to government expenditures, $g_{t}$. On the other hand, one can consider $g_{t}, z_{t}^{1-\theta}, 1-\tau_{h, t}$, and $\frac{1}{1+\tau_{x, t}}$ to be measures of the distortions that interfere with the economic agents' behavior in the equilibrium. Using the latter interpretation, $g_{t}$ measures the frictions that prevent aggregate supply from being equal to domestic private demand; $z_{t}^{1-\theta}$ measures the efficiency with which factor inputs are used in the production sector; $1-\tau_{h, t}$ measures the frictions that make the marginal rate of substitution of consumption for leisure deviate from the marginal product of labor; and $\frac{1}{1+\tau_{x, t}}$ measures the frictions that distort the intertemporal Euler equation. Thus, according to this second interpretation, the distorted equilibrium equations encompass more detailed models, that is, models with explicit frictions. CKM name the distortion measures as follows: $g_{t}$ is called the government consumption wedge, $z_{t}^{1-\theta}$ is called the efficiency wedge, $1-\tau_{h, t}$ is called the labor wedge, and $\frac{1}{1+\tau_{x, t}}$ is called the investment wedge.

CKM show that one can restate more detailed models as neoclassical growth models with one or several time-varying wedges. All of the terms that characterize the frictions in the detailed model are captured by the wedges ${ }^{4}$. Thus, a researcher who has identified the main wedges responsible for the economic fluctuations observed in the data is able to choose which family of detailed models she/he should use. To evaluate $P, P_{0}$, and $V$, CKM propose to estimate the stochastic exogenous process (6) using data on macroeconomic variables. The structural parameters are instead calibrated.

Theoretically, the realizations of the wedges are defined such that when they are fed back into the prototype model, the simulated variables perfectly match the data. Let $y_{t}^{d}, x_{t}^{d}, h_{t}^{d}$, and $c_{t}^{d}$ denote the data on output, investment, labor, and consumption, respectively. Additionally, let $y\left(k_{t}^{d}, S_{t}^{d}\right), x\left(k_{t}^{d}, S_{t}^{d}\right), h\left(k_{t}^{d}, S_{t}^{d}\right)$, and $c\left(k_{t}^{d}, S_{t}^{d}\right)$ represent the decision rules of the prototype model, where $k_{t}^{d}$ is a measure of the capital stock. The capital stock is constructed using the data on investment as follows: $\gamma_{n} \gamma_{z} k_{t+1}^{d}=(1-\delta) k_{t}^{d}+x_{t}^{d}$, where the initial

\footnotetext{
${ }^{3}$ Formally, $\gamma_{n}$ and $\gamma_{z}$ are defined as follows. $N_{t+1}=\gamma_{n} N_{t}$ and $Z_{t+1}=\gamma_{z} Z_{t}$, where $N_{t}$ and $Z_{t}$ denote the levels of the population and of the deterministic component of labor-augmenting technical progress, respectively.

${ }^{4}$ For instance, CKM demonstrate that a model with an input financing problem is equivalent to a prototype model with an efficiency wedge; a model with sticky wage and monetary shock is equivalent to a prototype model with a labor wedge; a model with an investment financing problem is equivalent to a prototype model with an investment wedge; and a model with international lending and borrowing is equivalent to a prototype model with a government consumption wedge. For more details, see Chari et al. (2004, 2007).
} 
value of capital, $k_{0}^{d}$, is assumed to be known and the parameters $\delta, \gamma_{n}$, and $\gamma_{z}$ are calibrated. Thus, the vector of realization of the wedges, $S_{t}^{d}$, solves the following system of equations $y\left(k_{t}^{d}, S_{t}^{d}\right)=y_{t}^{d}, x\left(k_{t}^{d}, S_{t}^{d}\right)=x_{t}^{d}, h\left(k_{t}^{d}, S_{t}^{d}\right)=h_{t}^{d}, c\left(k_{t}^{d}, S_{t}^{d}\right)=c_{t}^{d}$.

The contribution of each wedge or combination of wedges to movements in the real macroaggregates is evaluated through simulation exercises. We take an example to explain how to implement the decomposition step of the BCA method. Suppose that one wants to evaluate the effects of the efficiency wedge on output, labor, investment, and consumption. In this case, one has to cancel out the three other wedges - labor, investment, and government consumption wedges — such as they have no effect on the real macro-aggregates. In other words, one has to hold those three wedges fixed to their respective steady state value. To do so, one solves a variant of the prototype model in which only the efficiency wedge is time varying (efficiency wedge model). The effects of the labor, investment, and government consumption wedges on the expectations of future realizations of the efficiency wedge should not be neutralized. Let $y_{e}\left(k_{t}, S_{t}\right), x_{e}\left(k_{t}, S_{t}\right), h_{e}\left(k_{t}, S_{t}\right)$, and $c_{e}\left(k_{t}, S_{t}\right)$ denote the decision rules of the efficiency wedge model for output, investment, labor, and consumption, respectively. Then, one feeds the series for capital stock, $k_{t}^{d}$, and the constructed series for the wedges, $S_{t}^{d}$, into the efficiency wedge model decision rules. To evaluate the effects of the efficiency wedge on the movements of the real macro-aggregates, one simply compares the simulated series to empirical observations.

\section{The Historical Data}

This section presents the construction of historical data on output, consumption, investment, capital, and labor. These macroeconomic data are built consistently with the prototype model. The data set covers the period from 1896 to 1939, with the year as the time unit. We use the data collected by Villa $(1993)^{5}$. The national income account is used to construct data on output, consumption, investment, and capital. As a measure of labor, we use data on the average weekly number of hours worked per worker in firms and data on total employment ${ }^{6}$. Data on total population is used to calculate per capita measures of output, consumption, investment, capital, and labor.

\subsection{Output and its components}

Output is calculated by adding together real household consumption, real household investment, real firm investment, real government investment, real government consumption, and the real balance of trade ${ }^{7}$. In the prototype model, output is shared between consumption, investment, and a residual defined as the government consumption wedge. Thus, the prototype model's consumption variable is identified as real household consumption. The prototype model's investment variable includes real household investment, real firm investment, and real government investment.

\footnotetext{
${ }^{5}$ Villa (1993)'s data are freely available on the website of the CEPII: www.cepii.fr.

${ }^{6}$ Note that we do not use data on the average weekly number of hours worked per worker in the total economy (series dh in Villa, 1993) because this time series covers a shorter period. Nonetheless, those series fluctuate in close harmony, with a correlation of 0.995 between 1919 and 1939.

${ }^{7}$ The historical data on real household consumption, real household investment, real firm investment, real government investment, real government consumption, real exports, and real imports are labeled czm, izm, ize, izg, czg, expozt, and impozt, respectively, in Villa (1993). These data are all measured in billion francs of 1938. Another term should have been added to the sum to calculate the actual French real GDP: the real balance of utilization services (series susz in Villa, 1993) — services related to the international trade. However, there are missing observations for that time series during the period covering World War I. Because the share of the series susz in real GDP is small, the constructed measure of output is a good approximation of the actual real GDP.
} 
In the prototype model, output, consumption, and investment variables are defined in detrended per capita terms, so their respective empirical measures are first divided by the population time series ${ }^{8}$ and then divided by the long-run trend growth rate relative to a reference date. Before removing the deterministic trend from the data, the per capita series of output, consumption, and investment are divided by the 1929 value of per capita output. As a consequence, output is unity in 1929. In this way, the historical data will be defined using the same scale as the data generated by the prototype model. Formally, these operations are performed as follows: $d_{t}=\frac{D_{t} / N_{t}}{\left(\frac{Y_{\tau}}{N_{\tau}}\right)(1+g z)^{t-\tau}}, t=1896, \cdots, 1939$, where $D_{t}$ denotes the undetrended data, $Y_{t}$ the undetrended output, $N_{t}$ the population, $g z$ the long-run trend growth rate of $D_{t}$, and $d_{t}$ the detrended per capita data at period $t$. $\tau$ represents the reference date, 1929. Because it is assumed that output, consumption, and investment grow at a same rate in the prototype model, $g z$ is set equal to the geometric average growth rate of the constructed measure of output over the 1896-1939 period: $g z=1.15$ percent $^{9}$.

\subsection{Capital}

The constructed data on investment include investments made by firms as well as those made by households and the government. Therefore, Villa (1993)'s data on firm capital (labeled kze) might not accurately reflect our measure of investment. Thus, a new series for capital is constructed using the capital accumulation law defined in the prototype model and the constructed investment series: $(1+g z)(1+g n) k_{t+1}^{d}=(1-\delta) k_{t}^{d}+x_{t}^{d}, t=1896, \cdots, 1939$, where $x_{t}^{d}$ denotes the constructed series for investment and $k_{t}^{d}$ is the new series for capital. $g n=0.002$ is the average growth rate of the population, computed using population data from the 18961929 period. To generate a capital series with the previous equation, we still need an initial value for capital, $k_{1896}^{d}$, and need to assign a value to the capital depreciation rate, $\delta$. We divide Villa (1993)'s data on firm capital by the population series. In a second step, we divide the per capita series of firm capital by the 1929 value of per capita output and detrend the resulted series: $k_{t}^{f}=\frac{K_{t}^{f} / N_{t}}{\left(\frac{Y_{\tau}}{N_{\tau}}\right)(1+g z)^{t-\tau}}, t=1896, \cdots, 1939$, where $K_{t}^{f}$ is Villa (1993)'s data on firm capital and $\tau$ represents the reference year, 1929. We then assume that the new capital series, $k_{t}^{d}$, and Villa (1993)'s data on firm capital expressed in detrended per capita terms, $k_{t}^{f}$, take the same value in 1896. Finally, we calibrate the capital depreciation rate using the steady state expression of the capital accumulation law, firms' capital stock, $k_{t}^{f}$, and investment, $x_{t}^{d}$ : $\delta=1-(1+g z)(1+g n)+\overline{\left(\frac{x}{k^{f}}\right)}$, where $\overline{\left(\frac{x}{k^{f}}\right)}$ denotes the sample mean of the investment-capital ratio, $\frac{x_{t}^{d}}{k_{t}^{f}}$, over the $1896-1939$ period. Thus, $\delta$ is equal to 0.0664 .

\subsection{Labor}

In the prototype model, the labor variable is defined as the share of total time endowment an individual spends working each period. Thus, the empirical measure of this variable is computed

\footnotetext{
${ }^{8}$ The population series is labeled pop in Villa (1993).

${ }^{9}$ Choosing a value for $g z$ is not an easy task because the detrending procedure is extremely sensitive to this value. In their study of the French Great Depression, Beaudry \& Portier (2002) discussed different possible values of $g z$ (see Table 1 in Beaudry \& Portier, 2002). They chose the value of 2.98 percent for $g z$. This number corresponds to the average growth rate of French real GDP over the 1896-1994 period, excluding the periods covering the Great Depression period and the two World Wars. However, this value does not seem relevant if one wants to estimate a model for the period from 1896 to 1939. Indeed, we can show that the detrending procedure, with $g z=2.98$ percent, introduces a spurious decreasing trend in the data instead of removing the true increasing trend. A plot comparing the undetrended data with the detrended data (with $g z=2.98$ percent) is available upon request.
} 
as follows. The total number of hours worked for each period of the sample is calculated as $T H_{t}^{d}=E M P_{t}^{d} \times W H_{t}^{d} \times 52, t=1896, \cdots, 1939$, where $W H_{t}^{d}$ denotes the data on the average weekly number of hours worked per worker in firms and $E M P_{t}^{d}$ denotes the data on total employment(Villa, 1993, labeled dhe and emp, respectively). The number 52 refers to the number of weeks within a year. We express the total number of hours worked in per capita terms: $H_{t}^{d}=\frac{T H_{t}^{d}}{N_{t}}, t=1896, \cdots, 1939$. Finally, the series $H_{t}^{d}$ is divided by the total time an individual is, on average, endowed each period $(L)$ to obtain the empirical measure of labor $\tilde{h}_{t}^{d}$ : $\tilde{h}_{t}^{d}=$ $\frac{H_{t}^{d}}{L}, t=1896, \cdots, 1939$. We assume that each individual can allocate $L=4992$ hours per year between market and non-market activities ${ }^{10}$.

The time series for labor has missing observations between 1914 and 1918 and presents a decreasing trend over the 1896-1939 period. However, in the prototype model, it is assumed that labor is a stationary variable. Therefore, the labor series is detrended to remove the decreasing trend: $h_{t}^{d}=\frac{\tilde{h}_{t}^{d}}{(1+g h)^{t-\tau}}, t=1896, \cdots, 1913,1919, \cdots, 1939$, where $h_{t}^{d}$ is the detrended measure of labor and $g h$ is the average growth rate of labor ${ }^{11}$. The year of reference, $\tau$, is still set to 1929.

\section{Quantitative Analysis}

\subsection{Model solution}

The system of equilibrium equations of the prototype model is log-linearized in the neighborhood of the deterministic steady state. Then, the method developed by Klein (2000) is used to compute the decision rules from the obtained log-linear system of equilibrium equations.

\subsection{Prototype model parameter values}

To solve the prototype model, we need to assign values to the parameters and to the steady state levels of the wedges. The prototype model parameters can be partitioned into two sets. The first set gathers the structural parameters of the prototype model: $\Psi=\left\{\beta, \theta, \psi, \delta, \gamma_{z}, \gamma_{n}\right\}$. The second set gathers the parameters of the wedge process: $\Theta=\{P, Q\}$, where $Q$ is a lower triangular matrix, defined such that $Q Q^{\prime}=V$. The steady state levels of the wedges are stored in a third set: $\Delta=\left\{z, \tau_{h}, \tau_{x}, g\right\}$.

The elements in $\Psi$ and $\Delta$ are calibrated according to the long-run properties of the historical data, whereas the parameters belonging to $\Theta$ are estimated by maximum likelihood.

\subsubsection{Calibration}

The deterministic labor-augmenting technical progress gross growth rate, the population gross growth rate, and the capital depreciation rate were computed in the previous section: $\gamma_{z}=1.0115, \gamma_{n}=1.002$, and $\delta=0.0664$, respectively. The discount factor parameter, scaled by the deterministic labor-augmenting technical progress growth rate, $\frac{\beta}{\gamma_{z}}$, is set to 0.96 ; hence, $\beta=0.9710$. This value of the scaled discount factor is commonly used in the equilibrium business cycle literature. The values of $\beta$ and $\gamma_{z}$ imply a steady state real interest rate of about 4 percent per year. The capital share parameter, $\theta$, is set to 0.34, as in Beaudry \& Portier (2002). Those authors find that 66 percent of the output went to labor in the interwar period. The preference for leisure parameter, $\psi$, is normalized to unity.

\footnotetext{
${ }^{10} L=$ number of hours per day $(16) \times$ number of days per week $(6) \times$ number of weeks per year $(52)$.

${ }^{11} 1+g h=\left[\left(1+g h^{1}\right) \times\left(1+g h^{2}\right)\right]^{1 / 2}$, where $g h^{1}$ and $g h^{2}$ are the geometric average growth rates of labor over the 1896-1913 period and the 1919-1939 period, respectively.
} 
The steady state levels of the four wedges, collected into $\Delta$, are calibrated as follows. Using the historical data and the equilibrium equations, (3) and (4), we generate data for the efficiency and labor wedges, respectively: $z_{t}^{d}=\left(\frac{y_{t}^{d}}{\left(k_{t}^{d}\right)^{\theta}\left(h_{t}^{d}\right)^{1-\theta}}\right)^{\frac{1}{1-\theta}}$ and $\tau_{h, t}^{d}=1-\frac{\psi}{1-\theta} \frac{h_{t}^{d}}{1-h_{t}^{d}} \frac{c_{t}^{d}}{y_{t}^{d}}$, where $y_{t}^{d}$ is the constructed output series and $c_{t}^{d}$ is the constructed consumption series. We evaluate the steady state levels of the efficiency and labor wedges relative to their respective sample mean over the 1919-1929 period: $z=2.3747$ and $\tau_{h}=0.6035^{12}$. We use the equilibrium equation (2) to generate data for the government consumption wedge $g_{t}^{d}=y_{t}^{d}-c_{t}^{d}-x_{t}^{d}$. In other words, that wedge is measured by the sum of the public expenditures and balance of trade. At the end of World War I, France had a large trade deficit. It took France almost all of the 1920s to improve its balance of trade. Therefore, we set the steady state level of the government consumption wedge to its 1929 value $g=g_{1929}^{d}=0.0048$. Because the equilibrium equation (5) is expressed in terms of expectations, one cannot use it to generate a measure of the investment wedge. Instead, we use its steady state expression to evaluate its value: $\tau_{x}=\theta \overline{\left(\frac{y}{k}\right)}\left(\frac{\gamma_{z}}{\beta}-1+\delta\right)^{-1}-1$, where $\overline{\left(\frac{y}{k}\right)}$ denotes the sample mean of the output-capital ratio, $\frac{y_{t}^{d}}{k_{t}^{d}}$, over the 1919-1929 period. As a consequence, $\tau_{x}$ is set to 0.3539 . Table 1 summarizes the calibration of the parameters belonging to $\Psi$ and the steady state levels of the wedges, collected into $\Delta$.

Table 1: Calibration.

\begin{tabular}{l|c}
\hline Parameters & Values \\
\hline \hline Labor-augmenting technical progress growth rate $\gamma_{z}$ & 1.0115 \\
Population growth rate $\gamma_{n}$ & 1.002 \\
Discount factor $\beta$ & 0.971 \\
Capital share $\theta$ & 0.34 \\
Capital depreciation rate $\delta$ & 0.0664 \\
Preference for leisure $\psi$ & 1 \\
Steady state level of the efficiency wedge $z$ & 2.3747 \\
Steady state level of the labor wedge $\tau_{h}$ & 0.6035 \\
Steady state level of the investment wedge $\tau_{x}$ & 0.3539 \\
Steady state level of the government consumption wedge $g$ & 0.0048 \\
\hline
\end{tabular}

Table 2 compares the steady state implications of the prototype model, in terms of ratios, with the corresponding empirical quantities over different periods, that is, 1919-1929, 1896-1929, and 1896-1939. The prototype model reproduces quite well, in the steady state, the long-run properties of the historical data. Thus, the calibration described above seems acceptable.

Table 2: Steady state properties of the prototype model vs. long-run properties of the French data.

\begin{tabular}{c|c|c|c|c}
\hline Ratio & Prototype model & France 1919-1929 & France 1896-1929 & France 1896-1939 \\
\hline \hline$c / y$ & 0.8088 & 0.8089 & 0.8136 & 0.8133 \\
$x / y$ & 0.1858 & 0.2002 & 0.1897 & 0.1875 \\
$y / k$ & 0.4302 & 0.4137 & 0.4398 & 0.4251 \\
$k / h$ & 8.5245 & 8.8464 & - & - \\
$x / k$ & 0.0799 & 0.0831 & 0.0833 & 0.0799 \\
$y / h$ & 3.6671 & 3.6602 & - & - \\
\hline
\end{tabular}

\footnotetext{
${ }^{12}$ We skip the Great Depression period because that period would have too large an effect on the sample means because of the sample size. It would be better to include the pre-1919 period in the computation of the sample means of the wedges. However, because of missing observations in the historical measure of labor during World War 1, there are also missing observations in the measures of the efficiency and labor wedges over the 1914-1918 period.
} 


\subsubsection{Estimation}

To evaluate the parameters of the stochastic process (6), collected into $\Theta$, we first set up the decision rules of the prototype model in a state space form. Second, we estimate the state space form of the prototype model solution by maximum likelihood using the Kalman filter. The estimation of $\Theta$ is performed using the annual data on output, investment, labor, and consumption, covering the 1896-1939 period $^{13}$. To implement the maximum-likelihood estimation procedure, we assume that the data are generated by a Gaussian density. To avoid having large fluctuations in the government expenditures during World War I and at the end of the 1930s dominate the estimation of the stochastic process parameters, we restrict the shocks to the government consumption wedge to be orthogonal to the shocks to the other wedges. Therefore, matrices $P$ and $Q$ are defined as follows,

$$
P=\left(\begin{array}{cc}
\bar{P} & 0_{3 \times 1} \\
0_{1 \times 3} & p_{44}
\end{array}\right) \quad Q=\left(\begin{array}{cc}
\bar{Q} & 0_{3 \times 1} \\
0_{1 \times 3} & q_{44}
\end{array}\right)
$$

$\bar{P}$ is an $(3 \times 3)$ unrestricted matrix and $\bar{Q}$ is a $(3 \times 3)$ lower triangular matrix. $p_{44}$ and $q_{44}$ are scalars. The restrictions on matrices $P$ and $Q$ were suggested by CKM in their analysis of the U.S. Great Depression. The estimation results of the parameters of the stochastic process are displayed in Table 3 .

Table 3: Estimated parameters of vector AR(1) stochastic process.

Coefficient matrix $P$ on lagged states Coefficient matrix $\mathrm{Q}$ such that $V=Q Q^{\prime}$

$\left[\begin{array}{cccc}0.2810 & 1.0212 & 0.8148 & 0 \\ (0.2993)^{\mathrm{a}} & (0.7104) & (0.3663) & \\ -0.0092 & 0.9575 & 0.0239 & 0 \\ (0.0598) & (0.0979) & (0.0733) & \\ -0.3838 & 0.7781 & 1.3290 & 0 \\ (0.2486) & (0.5329) & (0.3086) & \\ 0 & 0 & 0 & 0.6172 \\ 0 & & & (0.1979)\end{array}\right]\left[\begin{array}{ccccc}0.0722 & 0 & 0 & 0 \\ (0.0080) & & & 0 \\ -0.0000 & 0.0149 & 0 & 0 \\ (0.0027) & (0.0023) & & 0.0160 \\ 0.0531 & -0.0264 & 0.0030) & (0.0000) & (0.0037 \\ (0.0108) & (0.0055)\end{array}\right]$

a Numbers in parentheses are quasi-maximum-likelihood standard errors (Hamilton, 1994).

\subsection{The wedges}

\subsubsection{Measuring the wedges}

Using the data on output, labor, investment, and consumption, we apply the Kalman filter and smoother on the state space form of the prototype model solution to obtain estimates of the realizations of the wedges ${ }^{14}$. Figure 1 displays the realizations of the wedges in France over

\footnotetext{
${ }^{13}$ We follow Harvey (1989, Section 3.4.7) in dealing with the missing observations in labor data when we estimate the prototype model. Following CKM, we add to the likelihood function a penalty term proportional to $\max \left(\left|\lambda_{P, \max }\right|-0.995,0\right)^{2}$, where $\lambda_{P, \max }$ stands for the maximal eigenvalue of $P$, to ensure the stationarity of the exogenous stochastic process for the wedges (the details of the maximum likelihood procedure are available upon request).

${ }^{14} \mathrm{CKM}$ propose to measure the efficiency, labor, and government consumption wedges using the equilibrium equations (2)-(4) and the investment wedge using the decision rules of the prototype model. Both methods give the same measures of the wedges.
} 
the 1929-1939 period. They appear in their respective distortive form, that is, in the way that they are identified in the equilibrium equations of the prototype model, (2)-(5). Although the government consumption wedge is given in levels, the efficiency, labor, and investment wedges are normalized to 100 in 1929. Efficiency and labor wedges decrease during the 1930s. In particular, the efficiency wedge decreases strongly between 1930 and 1936. After 1936, one can observe an attempt at a recovery, but it is not sustained because the efficiency wedge falls again from 1938 onward. The labor wedge falls dramatically between 1929 and 1932. It increases over the 1932-1936 period, but only slightly, as it remains below its 1929 level. Then, the labor wedge again drops sharply. The investment wedge remains above its 1929 level over the entire decade. The government consumption wedge fluctuates below its 1929 level between 1929 and 1937. It takes negative values several times over that period. During the last year of the decade, it increases dramatically.
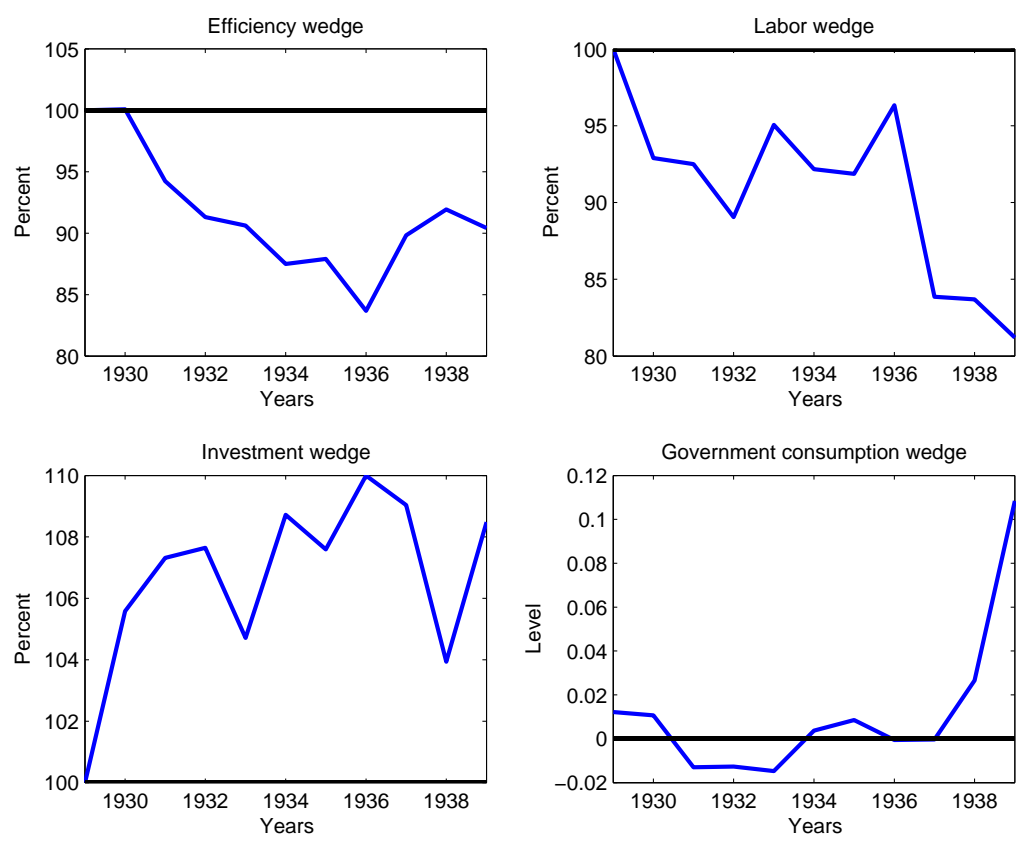

Figure 1: Wedges, 1929-1939.

\subsubsection{Interpreting the wedges}

\subsubsection{Efficiency wedge}

Several interpretations of the efficiency wedge have been suggested in the literature in the context of the U.S. Great Depression. Following Bernanke (1983), CKM demonstrate that the frictions created by the existence of unequal borrowing constraints, that is, a misallocation of inputs among firms, act in the detailed model in a way similar to the efficiency wedge in the prototype model. Therefore, financial frictions can manifest themselves as an efficiency wedge. Another interpretation of the efficiency wedge is offered by Crucini \& Kahn (2003). They demonstrate that a multi-sector dynamic equilibrium trade model is equivalent to the prototype model with a time-varying efficiency wedge. In other words, the frictions created by tariff policies can be captured by the efficiency wedge.

In studies on the Great Depression, financial frictions are usually related to the banking crises that took place in Central Europe and in the U.S. According to Lacoue-Labarthe (2005), France 
had experienced several bank runs during the 1930s. There were three waves of banking crises in France throughout the 1930s, October 1930 to January 1931, September to October 1931, and 1932 to 1933. The author argues that these banking panics were harmful to the financial intermediation market. Indeed, he shows that the banks that went bankrupt were primarily the most solvent ones. Lacoue-Labarthe (2005)'s claim is supported by the movement of the French money multiplier ${ }^{15}$. As shown in Figure 2, the latter sharply declined during the $1930 \mathrm{~s}^{16}$. Interestingly, Figure 2 shows that the fluctuations in the money multiplier are globally similar to those in the efficiency wedge between 1929 and 1936. Thus, the efficiency wedge might capture the distortions in the French financial market caused by the banking crisis.

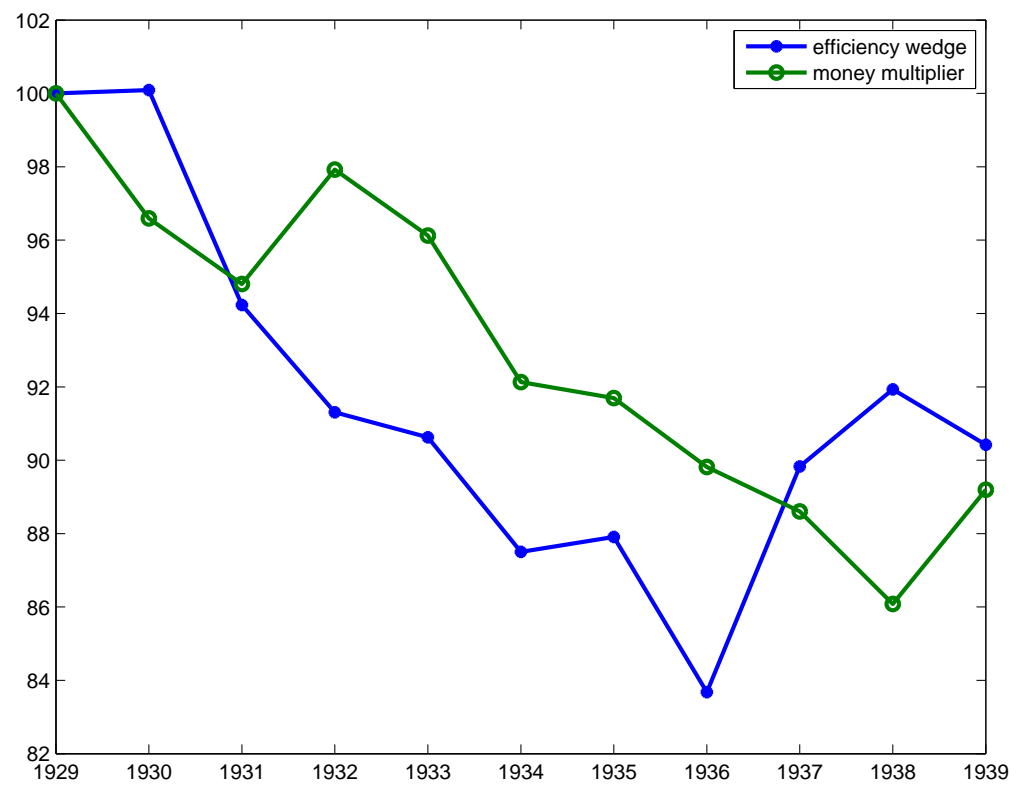

Figure 2: Efficiency wedge vs. money multiplier, 1929-1939. $1929=100$.

Following Crucini \& Kahn (2003), we construct a measure of the frictions created by the French tariff policies and compare it to the efficiency wedge. We compute an annual series of tariffs as the ratio of customs revenue to total imports over the 1929-1939 period $^{17}$. Figure 3

\footnotetext{
${ }^{15}$ Following Bernanke (1995), the money multiplier is defined by the ratio of monetary aggregate M1 to the monetary base. M1 is constructed by taking the sum of notes in circulation issued by the Bank of France (available in www.banque-france.fr under the label Billets au porteur en circulation) and commercial banks' and Bank of France's sight deposits (in Saint-Marc, 1983, col. Dépôts à vue, pp. 36-38). The monetary base is defined as being the sum of notes in circulation and the Bank of France liabilities on current account. The latter consist of the current account of the Treasury (in ww. banque-france.fr under the label Compte courant du Trésor), the current account of the autonomous sinking fund (in www.banque-france.fr under the label Compte courant de la Caisse Autonome d'Amortissement), current account and deposits (in www.banque-france.fr under the label Dispositions et autres engagements à vue), and other liabilities on current account (in ww. banque-france.fr under the label Dispositions et autres engagements à vue).

${ }^{16}$ As described by Bernanke (1995), banking crises lead the currency-deposit and bank reserve-deposit ratios to increase. As a consequence, the money multiplier drops.

${ }^{17}$ We take Villa (1993)'s data on import tax revenue (labeled dti) and real imports as a measure of the customs revenue and total imports, respectively. As the series dti is given in nominal terms, we divide it by the output deflator to put it in real terms. Both data on real customs revenue and real imports are expressed in per capita terms using the measure of population. The per capita measures of imports and customs revenue are then divided by the 1929 value of real per capita output and by the long-run growth rate relative to the reference period, 1929 . The output deflator is computed as the ratio of real output to nominal output. As we did for real output, we add together nominal household consumption (labeled cm in Villa, 1993), nominal household investment (labeled
} 
displays the fluctuations in the efficiency wedge and those in the tariffs over the Great Depression period. The tariffs increase throughout the 1930s, whereas the efficiency wedge drops. Moreover, it is worth noting that the efficiency wedge begins to drop when the tariffs move up, that is, in 1930. The negative correlation between the efficiency wedge and the tariffs is approximately -0.76 over the entire Great Depression period. It seems that French tariff policies may have caused, at least partly, the deterioration of the efficiency wedge during the 1930s.
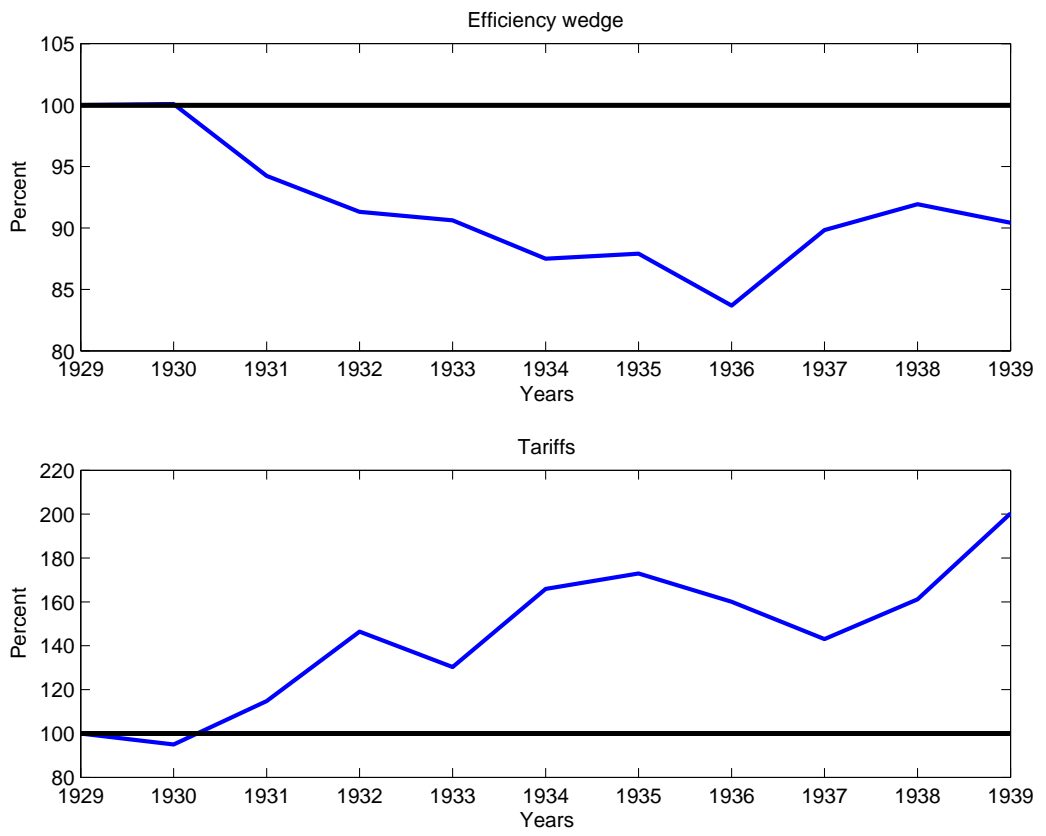

Figure 3: Efficiency wedge vs. tariffs. $1929=100$.

\subsubsection{Labor wedge}

Several interpretations of the labor wedge in the context of the U.S. economy have been suggested in the literature. According to one interpretation (Hall, 1997), the labor wedge captures labor market frictions that lead households to spend a great deal of time in non-market activities, such as job search. Mulligan (2002) finds that the labor wedge is well correlated with marginal labor tax rates in the long-run but not in the short-run, notably during the Great Depression. Galí et al. (2007) propose to decompose the labor wedge into price and wage markup components. This decomposition would allow them to identify which types of frictions have the greatest effect: those related to the goods market or those related to the labor market. The former are captured by the price markup, whereas the latter are captured by the wage markup. They find that most of the volatility of the labor wedge comes from fluctuations in the wage markup. Following Bordo et al. (2000) and Cole \& Ohanian (2004), CKM claim that during the 1930s, the labor wedge captured the frictions that had been caused by money supply contractions and workers' monopoly power. Interestingly, this interpretation of the labor wedge can be related to the gold standard-based explanation of the Great Depression(Eichengreen \& Sachs, 1985). The labor wedge would play the role of channeling the transmission of monetary shocks to

im in Villa, 1993), nominal firm investment (labeled ie in Villa, 1993), nominal government investment (labeled ig in Villa, 1993), nominal government consumption (labeled cg in Villa, 1993), and nominal balance of trade (labeled export minus import in Villa, 1993) to obtain a measure of nominal output. 
the real economy, induced by the malfunctioning of the gold standard. Shimer (2009) suggests that the labor wedge can capture labor market search and matching frictions à la Pissarides (1985) and Mortensen \& Pissarides (1994). In models with such frictions, the labor market has two main characteristics. First, household labor supply behavior is defined by the decision of whether to work rather than by the decision of how many hours to work. Second, firms and households spend costly time seeking partnerships and then negotiate a wage that lies between the marginal product of labor (MPL) and the marginal rate of substitution of consumption for leisure (MRS). As a consequence, fluctuations in the labor wedge can be caused by search and matching frictions.

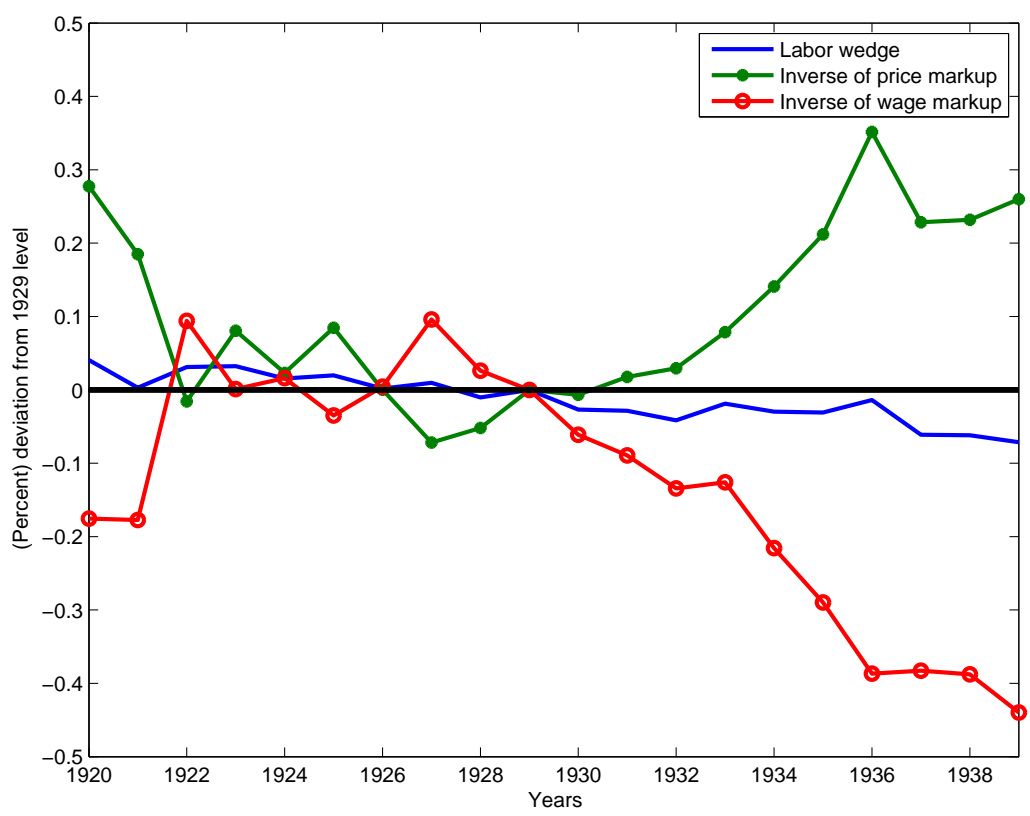

Figure 4: Labor wedge, price markup, and wage markup. In deviation, $1929=0$.

Following Galí et al. (2007), we restate the labor wedge as a negative function of the price and wage markups. The price markup is defined as the ratio of the MPL to the real wage, whereas the wage markup is defined as the ratio of the real wage to the MRS. Using historical data, we construct measures of the price and wage markups ${ }^{18}$. Figure 4 reports fluctuations in the labor wedge, the inverse of the price markup, and the inverse of the wage markup over the 1920-1939 period. It indicates that the decline in the labor wedge throughout the 1930s is primarily explained by the wage markup. The inverse of the price markup increases during the Great Depression, whereas the inverse of the wage markup decreases. Nonetheless, the move in the wage markup is larger than the move in the price markup. As a consequence, the labor wedge declines. Table 4, summarizing the second moments of the labor wedge and the markups, also demonstrates that the drop in the labor wedge is primarily due to the increase in the wage markup. Indeed, the labor wedge is strongly and negatively correlated with the wage markup and weakly positively correlated with the price markup.

It is worth investigating the characteristics of the French labor market during the interwar period, summarized in Table 5, to understand the frictions captured by the wage markup. The degree of nominal wage flexibility is often taken as an indicator of frictions in the labor market. During the first three years of the 1930s, the real wage remained quite close to its 1929 level. It

\footnotetext{
${ }^{18}$ The decomposition of the labor wedge into price and wage markup components is detailed in Appendix B.
} 
Table 4: Basic statistics on the labor wedge and markups, 1920-1939.

\begin{tabular}{cccccc}
\hline \hline & & & & \multicolumn{2}{c}{ Cross-Correlation } \\
\cline { 3 - 6 } Variable & std $(\%)^{\mathrm{a}}$ & $\operatorname{corr}\left(x_{t}, x_{t-1}\right)^{\mathrm{b}}$ & Labor wedge & Price markup & Wage markup \\
\hline Labor wedge & 3.23 & 0.79 & 1 & & \\
Price markup & 12.38 & 0.75 & 0.32 & 1 & \\
Wage markup & 16.91 & 0.87 & -0.72 & -0.89 & 1 \\
\hline \hline
\end{tabular}

a std: standard deviations.

$\mathrm{b} \operatorname{corr}\left(x_{t}, x_{t-1}\right)$ : autocorrelations.

then increased, mostly between 1934 and 1936. Because the Great Depression was a deflationary period in France, the increase in the real wage means that the nominal wage was sticky at that time. This raises the question of whether unions were strong enough to ensure that workers were paid higher wages. Table 5 presents three measures of the strength of unions: number of strikes, number of collective bargaining agreements, and union membership. Clearly, unions could not have significantly increased the nominal wage during the first half of the decade because they were weak. Indeed, the number of strikes and the number of collective bargaining agreements decreased between 1929 and 1931 and then remained at a low level until 1935. Memberships in the two main unions - CGT and CGTU ${ }^{19}$ — declined between 1930 and 1934. After 1935, the situation was reversed. Table 5 shows that the number of strikes and the number of collective bargaining agreements sharply increased in 1935 and 1936. In March 1936, the unions CGT and CGTU were reunified, leading to a sharp increase in reunified CGT membership. In 1935, leftist organizations such as unions and left-wing political parties rallied behind one political and social project: the Front Populaire. After having won the legislative elections of May 1936, the government of the Front Populaire, led by Léon Blum, put several labor market reforms into motion.

The reforms (wage levels, collective bargaining, paid vacations, reduction of the length of the workweek without lowering nominal wages) were supposed to free the country from the economic slump. The nominal wage increase would stimulate demand and, therefore, economic activity. The forty-hour week would solve the unemployment problem. According to the authors of the law, reducing the length of the workweek would free working time that could be filled by the unemployed. The implied increase in employment was expected to offset the reduction of the length of the workweek so that the total hours worked would not decline. It seems that Blum's government did not achieve its economic goal, as the French economy did not recover after 1936. However, the Front Populaire's policies might have distorted the labor market. Indeed, Figure 1 shows that the labor wedge strongly decreases between 1936 and 1937. The reduction of the length of the workweek can be harmful for the economy because the argument on which the law is based is misleading (Sauvy, 1984). Indeed, the argument would be accurate if all the available workers are substitutable and mobile, which was not the case. As shown by Figure 5 , the decrease in the number of hours worked per worker each year is larger than the increase in the ratio of employment to population between 1936 and 1939. As a result, the total hours worked per capita decline between 1936 and 1939.

Turning to monetary policy, Figure 6 displays the fluctuations in the nominal interest rate ${ }^{20}$

\footnotetext{
${ }^{19}$ The two main unions were the Confédération Générale du Travail (CGT) and the Confédération Générale du Travail Unitaire (CGTU).

${ }^{20}$ We use Villa (1993)'s data on money market rate (labeled txmm) to measure the nominal interest rate.
} 
Table 5: The French labor market characteristics.

\begin{tabular}{|c|c|c|c|c|c|c|c|c|}
\hline Year & Real wage $^{\mathrm{a}}$ & Year & Strikes $^{b}$ & Collective bargaining $^{\mathrm{b}}$ & & Divide & $\mathrm{CGT}^{\mathrm{c}}$ & ${\text { United } \mathrm{CGT}^{\mathrm{C}}}$ \\
\hline 1929 & 100 & 1929 & 1213 & 112 & Year & CGT & CGTU & CGT \\
\hline 1930 & 101.10 & 1930 & 1093 & 72 & 1926 & 525,788 & 431,240 & - \\
\hline 1931 & 100.86 & 1931 & 261 & 17 & 1928 & 554,796 & 370,260 & - \\
\hline 1932 & 101.53 & 1932 & 330 & 23 & 1930 & 577,280 & 322,545 & - \\
\hline 1933 & 104.28 & 1933 & 331 & 20 & 1932 & 533,197 & 258,275 & - \\
\hline 1934 & 106.94 & 1934 & 361 & 24 & 1934 & 491,014 & 264,085 & - \\
\hline 1935 & 114.57 & 1935 & 420 & 29 & 1935 & - & - & $785,728^{\mathrm{d}}$ \\
\hline 1936 & 123.25 & 1936 & 17087 & 2336 & 1937 & - & - & $4,081,239$ \\
\hline 1937 & 119.14 & 1937 & 3680 & 2259 & & & & \\
\hline 1938 & 122.34 & 1938 & 780 & - & & & & \\
\hline 1939 & 120.25 & & & & & & & \\
\hline
\end{tabular}

${ }^{a}$ Real wage is defined as the ratio of nominal wage to price. Villa (1993)'s data on hourly nominal wage in firms (labeled whpe) and the output deflator are taken as measures of the nominal wage and price, respectively. Then, the ratio of nominal wage to price is divided by the average growth rate of output relative to the 1929 reference date.

$\mathrm{b}$ The data on strikes represent the number of strikes that took place each year between 1929 and 1939. The data on collective bargaining agreements correspond to the number of negotiations between firms and unions that ended well over the 1929-1939 period. These data on strikes and collective bargaining agreements are taken from (Colton, 1951, Table 2, p. 14; Table 7, p. 110) and (Sauvy, 1984, vol. 2, p. 226).

c The data on union memberships represent the number of workers that subscribe to CGT and CGTU one year before each union's congress. Those meetings took place in 1927, 1929, 1931, 1933, 1935, 1936, and 1938. The data on union memberships are taken from Prost (2006).

d The 1935 value corresponds to the sum of the size of CGT membership and the size of CGTU membership, as these unions reunified in May of 1936.

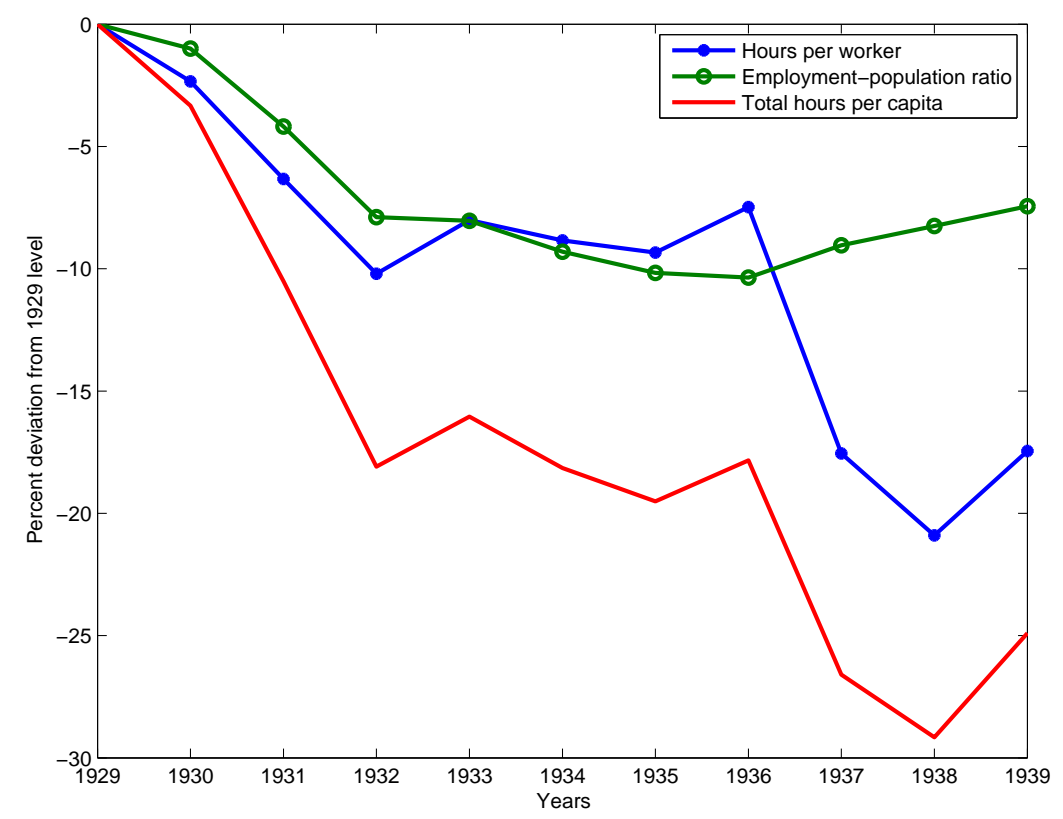

Figure 5: Decomposing the hours worked. 
and those in the labor wedge during the Great Depression period. It seems that monetary forces did not play an important role in the labor wedge fluctuations. Indeed, the labor wedge sharply decreases during the first year of the decade, whereas the nominal interest rate is reduced. The increase in the nominal interest rate that occurred between 1931 and 1936 did not have a strong negative effect on the labor wedge, as the latter remained stable, though at a low level, during that period.
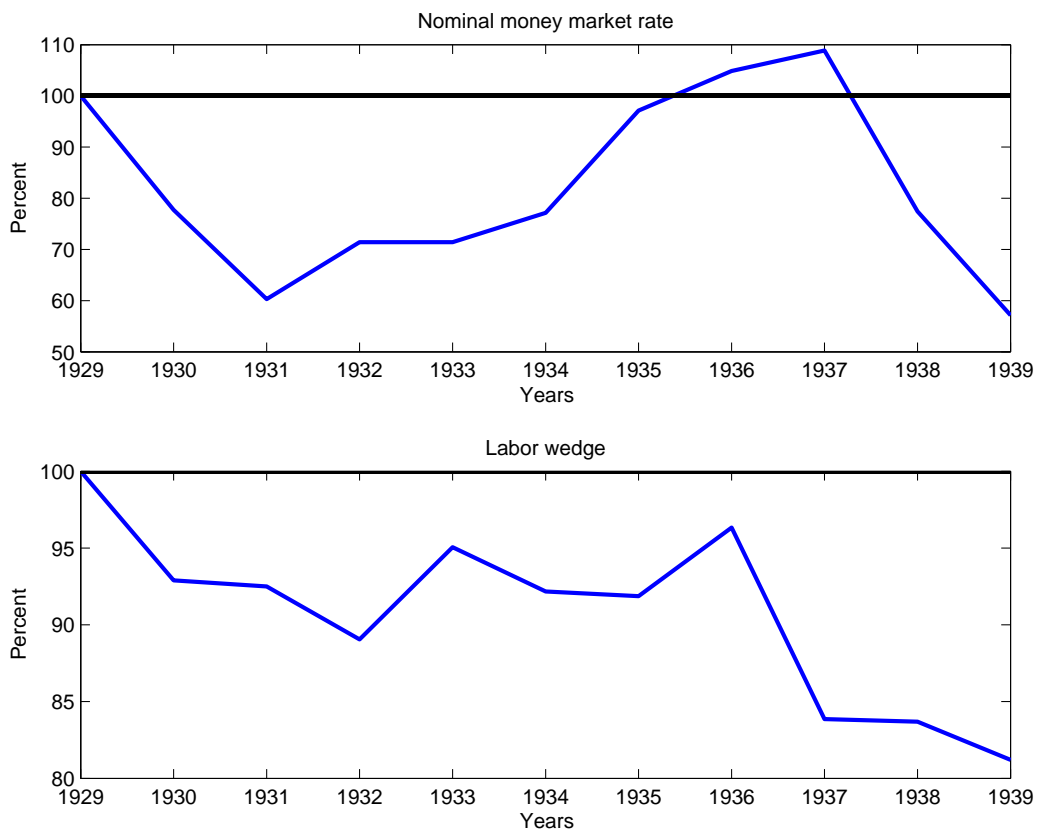

Figure 6: Labor wedge vs. nominal money market rate. $1929=100$.

To assess whether labor tax policies are responsible for the decrease in the labor wedge, we use a measure of the social security contributions of firms as a proxy for the labor tax ${ }^{21}$. Table 6 reports the labor tax rate and the levels of $\tau_{h, t}$ over the 1929-1939 period. Clearly, the two variables do not follow the same pattern. Indeed, the labor tax rate is constant during almost the entire the decade, whereas $\tau_{h, t}$ appears more volatile. Additionally, $\tau_{h, t}$ takes larger values than the labor tax rate.

To assess whether search and matching frictions could be relevant for the understanding of the behavior of the labor wedge, Figure 5 displays the movements in hours worked (hours per capita), the employment-population ratio, and the hours worked per worker (hours per worker). It seems that search and matching models are not useful in understanding the French labor market during the Great Depression. Indeed, between 1929 and 1936, the hours worked per worker and the employment-population ratio equally account for the fluctuations in the hours worked. In the remainder of the decade, the employment-population ratio increases slightly, whereas the hours worked per worker sharply decrease. Thus, the decision of whether to work and the decision of how many hours to work seem equally important in understanding the fluctuations in hours worked between 1929 and 1936. During the Front Populaire and later, the drop in hours worked can be explained only by household decisions of how many hours to work.

\footnotetext{
${ }^{21}$ The labor tax rate series is constructed using Villa (1993)'s data on social contributions firms had to pay when they are using labor inputs (labeled tcsex).
} 
Table 6: Labor wedge vs. labor tax rate. Source: Villa (1993).

\begin{tabular}{ccc}
\hline \hline Year & $\tau_{h, t}$ & Labor tax rate \\
\hline 1929 & 0.6207 & 0.01 \\
1930 & 0.6477 & 0.02 \\
1931 & 0.6492 & 0.03 \\
1932 & 0.6623 & 0.03 \\
1933 & 0.6395 & 0.03 \\
1934 & 0.6504 & 0.03 \\
1935 & 0.6516 & 0.03 \\
1936 & 0.6347 & 0.03 \\
1937 & 0.6819 & 0.03 \\
1938 & 0.6826 & 0.03 \\
1939 & 0.6920 & 0.03 \\
\hline \hline
\end{tabular}

\subsubsection{Investment wedge}

CKM claim that the time-varying investment wedge is primarily driven by particular financial frictions. They demonstrate that the model of Carlstrom \& Fuerst (1997) (CF) displays financial frictions that act in a manner similar to the investment wedge in the prototype model. Those frictions arise because firm loans are constrained by their net worth due to an agency problem. In particular, CF's model is equivalent to a prototype model including the efficiency wedge, the investment wedge, and the government consumption wedge. The financial frictions that are measured by the price of capital (or Tobin's $q$ ), $q_{t}$, in CF's model, are captured by the investment wedge in the prototype model ${ }^{22}$ (see Chari et al., 2004). Formally, the relationship between the investment wedge and the price of capital is given by $\frac{1}{1+\tau_{x, t}}=\frac{1}{q_{t}}$.

To evaluate whether the investment wedge captures the frictions created by CF's agency problem, we compare the fluctuations in the French Tobin's $q$ to those in the investment wedge ${ }^{23}$. Figure 7 highlights the close correlation between the inverse of Tobin's $q$ and the investment wedge throughout the interwar period, particularly during the 1930s. The investment wedge increases throughout the 1930s, whereas output drops. This means that if this wedge must be seriously considered, CF's model including an aggregate technology shock might be a good starting point to study the French Great Depression.

\subsubsection{Government consumption wedge}

In the prototype model, the government consumption wedge, $g_{t}$, which acts in the resource constraint, measures the discrepancy between output, $y_{t}$, and the domestic private demand, $c_{t}+x_{t}$. Roughly speaking, this wedge captures frictions that take place in the international trade sector or the public sector. CKM demonstrate that a detailed model with international lending and borrowing is equivalent to a prototype model including only the government consumption wedge. Specifically, they show that the government consumption wedge is measured by net exports in the detailed model.

\footnotetext{
${ }^{22}$ The efficiency wedge corresponds to the aggregate technology shock in CF's model. The government consumption wedge includes the consumption of entrepreneurs.

${ }^{23}$ We follow Eichengreen \& Wyplosz (1986) in the construction of a time series for French Tobin's $q: q_{t}=$ Shareprices . Cost of capital goods is obtained from Carré et al. (1972, Table 3, p.652). It is measured by the weighted average of the relative price of output of mechanized industries (prix relatifs biens des industries mécaniques) and buildings (prix relatifs constructions). The weights are respectively given by the volume of investment in capital equipment (investissement en matériels) and building and public works (bâtiment et travaux publics). Share prices are obtained from Sauvy (1984, Table XIII-1, vol. 3, p. 398). They are measured by the index of French stock prices (indice mensuel des valeurs françaises à revenu variable).
} 


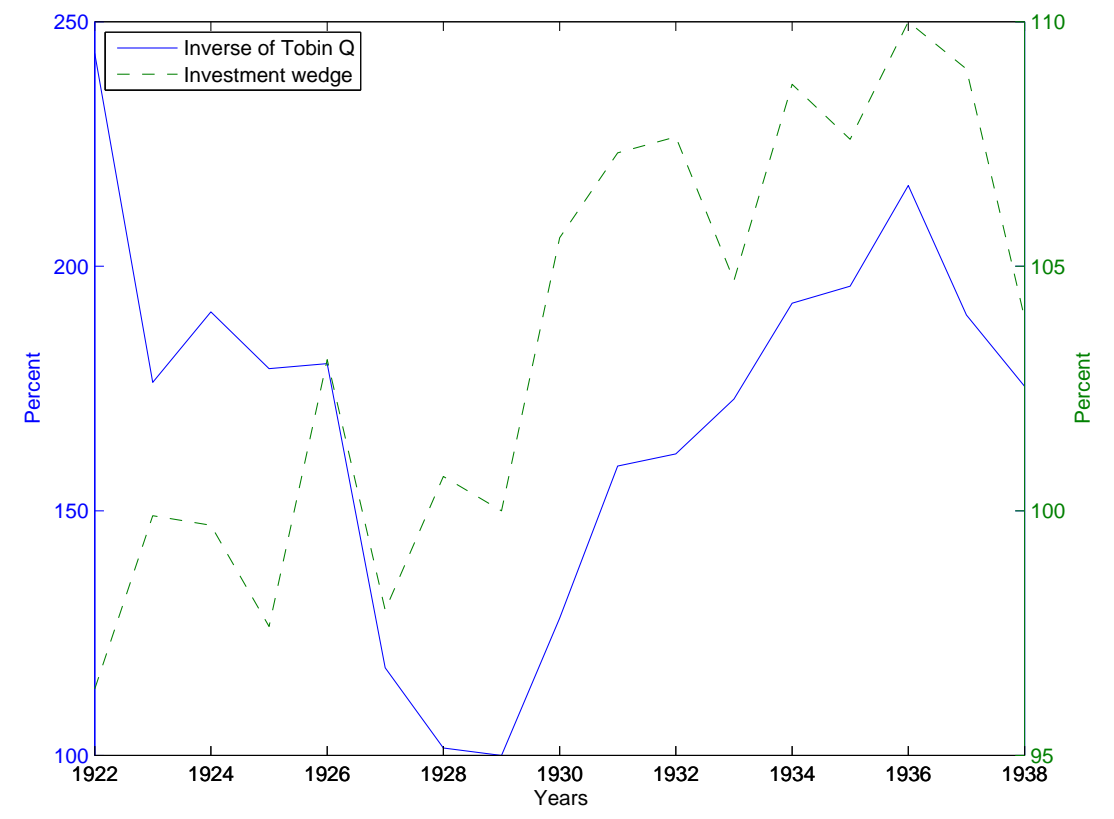

Figure 7: Investment wedge vs. Tobin's $q, 1929=100$.

As noted above, during the Great Depression in France, the government consumption wedge fluctuates below its 1929 value until 1937 and then dramatically increases. The wedge takes negative values between 1930 and 1933 and between 1936 and 1937. Sauvy (1984) noted that French prices increased significantly relative to those of other countries during the 1930s. He showed that French prices were higher than English prices during the first five years following the pound devaluation, that is, between 1931 and 1936. The ratios of French prices to English prices from 1931 to 1939 are reported in Table 7. Sauvy (1984) claimed that the discrepancy between the French prices and those of other countries played an important role in the economic crisis. Because the French prices relatively increased, France lost its international competitiveness. As a consequence, export-oriented firms decreased their production.

Table 7: Ratio of French prices to English prices from 1931 to 1939. Source: Sauvy (1984).

\begin{tabular}{c|c|c|c|c|c|c|c|c|c}
\hline \hline Year & 1931 & 1932 & 1933 & 1934 & 1935 & 1936 & 1937 & 1938 & 1939 \\
Ratio $^{\mathrm{a}}$ & 0.93 & 1.13 & 1.16 & 1.22 & 1.15 & 1.07 & 0.85 & 0.70 & 0.73 \\
\hline \hline
\end{tabular}

a Sauvy (1984) constructed the ratio of French price to English price using the index of cost of living evaluated in gold of both countries and assuming that the French prices are 22 percent higher than the English price in February 1935.

Sauvy's hypothesis can be captured by the government consumption wedge. Indeed, the loss of international competitiveness during the 1930s might have driven the wedge downward and to negative values. Figure 8 compares the fluctuations in the wedge (reported in levels) to those of an index of competitiveness over the 1931-1939 period. The index of competitiveness is simply calculated as the inverse of the ratio of French price to English price. The wedge becomes negative when the index of competitiveness decreases. Moreover, the correlation between the wedge and the index of competitiveness is 0.67 . The strong increase in the government consumption wedge during the last two years of the decade may also be related to the military expenditures 
in expectation of a war.
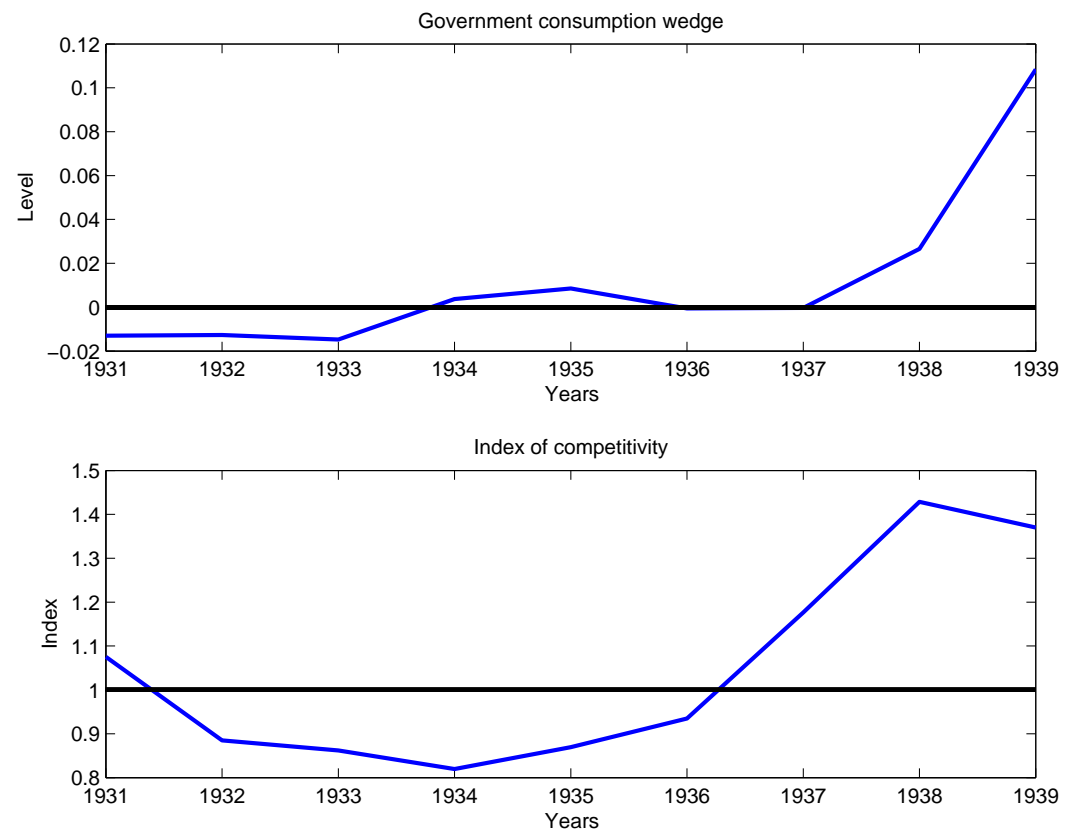

Figure 8: Government consumption wedge vs. the index of competitiveness.

\subsection{Decomposition}

In this subsection, we evaluate the contribution of each wedge and different combinations of wedges to the fluctuations in output, labor, investment, and consumption that occurred in France during the Great Depression. To do so, we perform the decomposition step of the BCA method. The simulations assume that the prototype model is in the steady state in 1929. Indeed, the French economy is close to its balanced growth path in 1929. To compare the simulated series with the data, we normalize the artificial series and the historical data to 100 in 1929. Because we found that the government consumption wedge does not explain the observed fluctuations in output, consumption, labor, and investment over the 1930s, we focus only on the fluctuations caused by the efficiency, labor, and investment wedges.

\subsubsection{The contribution of the efficiency wedge}

We simulate a variant of the prototype model where only the efficiency wedge is timevarying (EW model). Figure 9 compares the predictions of the EW model to the historical data on output, labor, investment, and consumption over the 1929-1939 period. The EW model performs quite well in tracking the observed downward movement in output and labor. The EW model predicts that investment also declines over the decade, although the drop in the simulated investment is larger than the actual one. However, the downturn in consumption is not captured by the efficiency wedge. Not only does the wedge weakly affect consumption, but it also increases the latter.

The frictions captured by the efficiency wedge led to an inefficient use of the factor inputs labor and capital - which resulted in the decline of labor, investment, and output. However, that wedge does not directly affect the consumption decision. This fact can explain the weak effects of the wedge on consumption. 

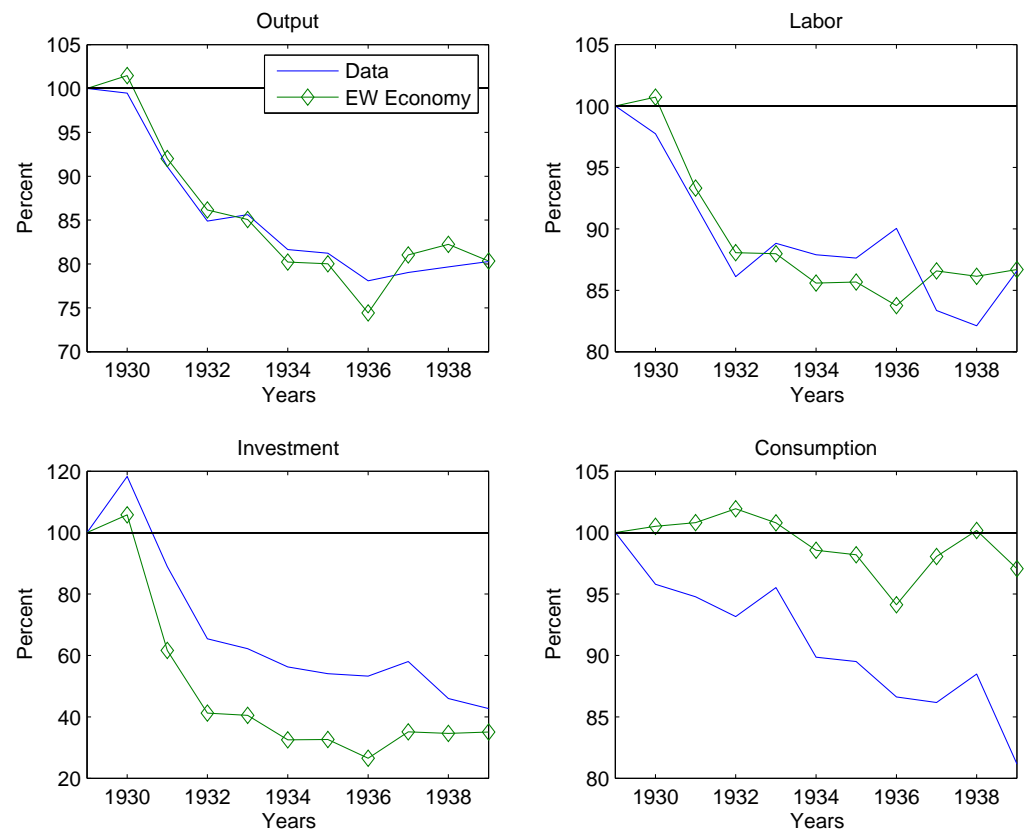

Figure 9: Data and predictions of the EW model, 1929-1939. $1929=100$.

\subsubsection{The contributions of the labor and investment wedges}

We simulate two variants of the prototype model. In the first one, only the labor wedge is time-varying (LW model). In the second one, only the investment wedge is time-varying (IW model). Figure 10 compares the predictions of the LW and IW models to the historical data on output, labor, investment, and consumption over the 1929-1939 period.

The labor wedge can be considered an important factor of the Great Depression only after 1936. Indeed, the contribution of that wedge to the fluctuations of output, investment, and consumption becomes significant only after that date, that is, during the Front Populaire period. Additionally, although the simulated labor and the actual labor follow the same pattern, the contribution of the labor wedge is less important than the contribution of the efficiency wedge.

The investment wedge fails to explain the observed fluctuations in output, labor, and investment, as that wedge leads those variables in the wrong direction. The trend is different for consumption. The investment wedge accounts for a small, but non-negligible, part of the observed movements in consumption.

\subsubsection{The join contributions of the wedges}

Above, we have shown that the efficiency wedge accounts for a large fraction of the fluctuations in output, labor, and investment, but it plays no role in the fluctuations in consumption. To support this result, we simulate a variant of the prototype model where the efficiency wedge is fixed to its steady state level (No-EW model). As shown in Figure 11, in the absence of the efficiency wedge, the prototype model fails to replicate the fluctuations in output, labor, and investment but accurately tracks the fluctuations in consumption.

We have also shown that the investment wedge contributes only to the decline of consumption. To give support to this result, we simulate a variant of the prototype model in which the investment wedge is fixed to its steady state level (No-IW model). In this case (11), the prototype model predicts a larger drop of output, labor, and investment and a milder decrease 

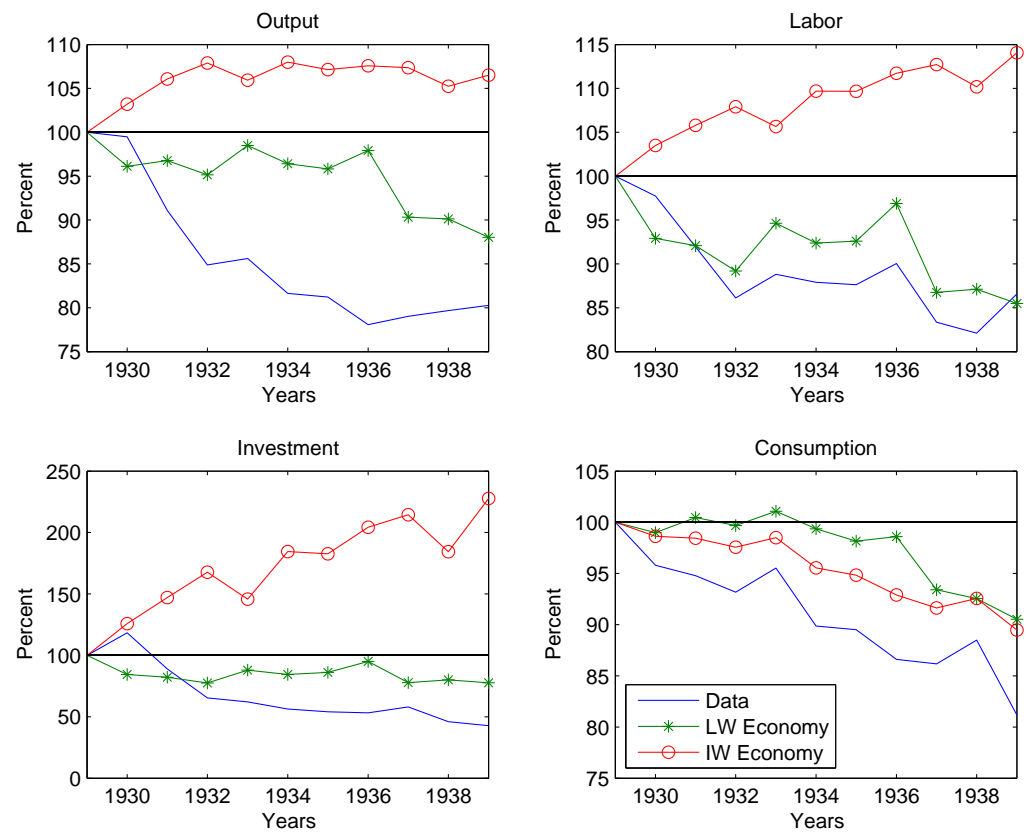

Figure 10: Data and predictions of the LW and IW models, 1929-1939. $1929=100$.
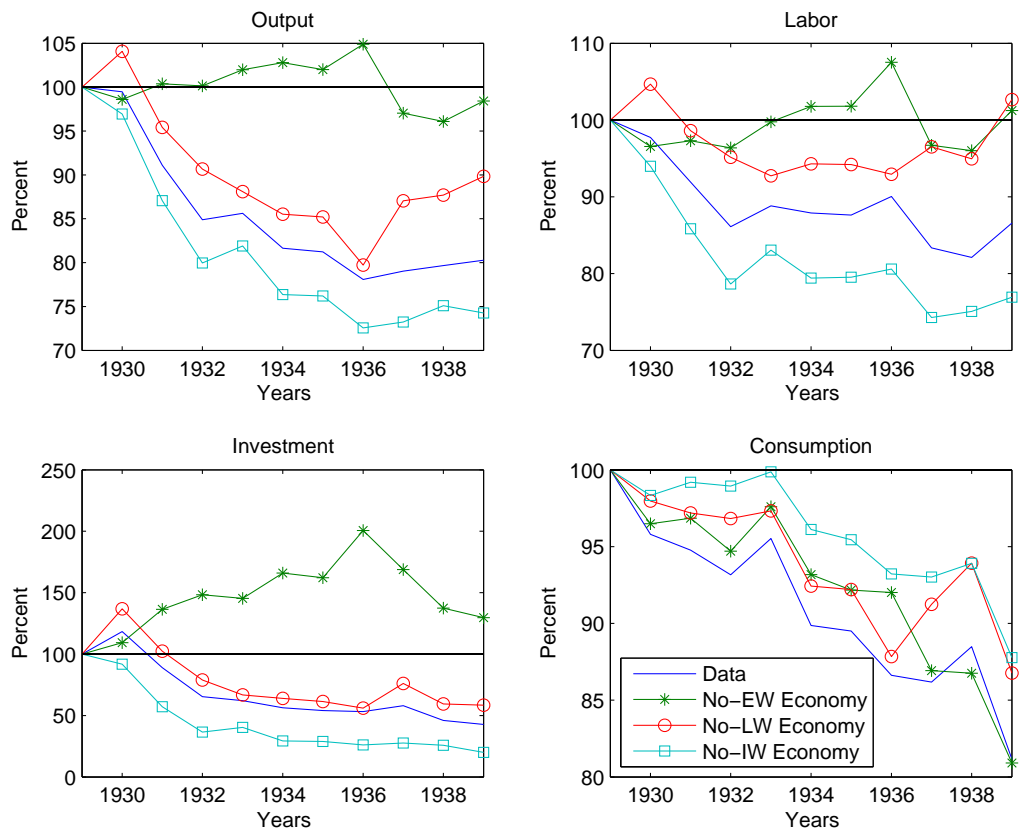

Figure 11: Data and predictions of the No-EW, No-LW, and No-IW models, 1929-1939. $1929=100$. 
of consumption than what is observed in the data.

Finally, we found that the labor wedge contributes to the French Great Depression mainly after 1936. This result can also be shown by simulating a variant of the prototype model in which the labor wedge is fixed to its steady state level (No-LW model). As one can see in Figure 11, the No-LW model predicts that output, labor, investment, and consumption increase after 1936, whereas they remain at a low level in the data.

Hence, the efficiency wedge appears to be the main culprit of the French Great Depression. Financial frictions and/or tariff policies might be the primary factors in the decline in that wedge. The investment and labor wedges only play a secondary role in the episode. The former can account for a non-negligible fraction of the decrease in consumption, whereas the latter can explain why output, labor, investment, and consumption remain at a low level after 1936. The investment wedge might capture financial frictions due to an agency problem (as in Carlstrom \& Fuerst, 1997). The Front Populaire policies might be an important factor in the decline of the labor wedge after 1936.

\section{Conclusion}

Beaudry \& Portier (2002) showed that the French Great Depression cannot be explained by total factor productivity (TFP). The results presented here shed new light on the depression in France during the 1930s. Using the BCA framework, the paper demonstrates that frictions captured by TFP, labeled the efficiency wedge by CKM, are the primary factor in the economic downturn. The efficiency wedge contributes to a large fraction of the decline in output, labor, and investment but accounts for almost nothing in the drop of consumption. Investment and labor wedges play a secondary role: the investment wedge can explain a non-negligible share of the fluctuations in consumption, and the labor wedge might have been a burden on the economy after 1936. The government consumption wedge has almost no effect on the economy. The paper provides some interpretations of the wedges. Financial frictions and tariff policies may have been the major causes of the decline in the efficiency wedge. The investment wedge might capture financial frictions that arise from agency costs (as in Carlstrom \& Fuerst, 1997). The deterioration of the labor wedge after 1936 might have resulted from institutional changes in the labor market (Front Populaire reforms). Although those results do not close the debate on

the French Great Depression, they suggest that the frictions that undermine the efficiency with which factor inputs are used are crucial for the understanding of the period. 


\section{A The Benchmark Prototype Model}

In this appendix, we describe the prototype model developed by CKM. Consider a closed, real economy where there are three infinitely living agents — households, firms, and a government two markets - the goods and labor markets - and homogeneous goods produced by firms. Both markets are competitive. The goods could be used as private consumption goods, investment goods or public consumption goods. In the following, we present the structure of this economy directly using per capita and detrended variables.

The preferences of the representative household are described by an expected intertemporal utility function,

$$
E_{0} \sum_{t=0}^{+\infty}\left(\beta \gamma_{n}\right)^{t}\left[\log \left(c_{t}\right)+\psi \log \left(1-h_{t}^{s}\right)\right] \quad 0<\beta<1, \gamma_{n}>1
$$

where $h_{t}^{s}$ denotes labor supply. The intratemporal budget constraint of the household is

$$
c_{t}+\left(1+\tau_{x, t}\right) x_{t}=\left(1-\tau_{h, t}\right) w_{t} h_{t}^{s}+r_{t} k_{t}+t r_{t}
$$

where $t r_{t}$ denotes the lump-sum transfers, $w_{t}$ the real wage rate, and $r_{t}$ the capital real rental rate. The left-hand side of (8) describes the uses of household wealth, whereas the right-hand side describes the sources of this wealth. The household buys consumption goods, $c_{t}$, and investment goods, $x_{t}$. It receives a wage bill for the total amount $w_{t} h_{t}^{s}$ and a capital rent bill for the total amount $r_{t} k_{t}$. Its also receives a lump-sum transfer, $t r_{t}$, from the government. It pays taxes on labor, $\tau_{h, t} w_{t} h_{t}^{s}$, and on investment, $\tau_{x, t} x_{t}$, to the government. The household uses its investment to accumulate its stock of capital as in (1). The household is supposed to choose consumption, investment, and labor supply sequences that maximize (7), subject to (8) and (1), taking the real wage rate, the real capital rental rate, and the tax rates as given.

The representative firm uses a constant return to scale Cobb-Douglas technology to produce

$$
y_{t}=\left(k_{t}^{D}\right)^{\theta}\left(z_{t} h_{t}^{D}\right)^{1-\theta} \quad 0<\theta<1
$$

where $k_{t}^{D}$ is the demand for capital and $h_{t}^{D}$ is the demand for labor. Each period, the firm chooses the quantities of capital and labor inputs it needs to maximize its profits $\pi_{t}=y_{t}-r_{t} k_{t}^{D}-w_{t} h_{t}^{D}$, subject to (9) and taking the level of the stochastic component of the labor-augmenting technical progress, $z_{t}$, the real wage rate, and the real capital rental rate as given.

The government raises taxes on labor and investment and makes public expenditures. It uses lump-sum transfers to households (or from households, if these transfers are negative) to balance its budget constraint: $g_{t}+t r_{t}=\tau_{h, t} w_{t} h_{t}^{s}+\tau_{x, t} x_{t}$.

The tax rates, government expenditures, and the level of the stochastic component of the labor-augmenting technical progress are exogenously given by (6).

A decentralized competitive equilibrium is defined by (i) allocations $c_{t}, h_{t}^{s}, k_{t+1}, x_{t}$ that solve the representative household's problem, taking all prices and tax rates as given; (ii) allocations $y_{t}, h_{t}^{D}, k_{t}^{D}$ that solve the representative firm's problem, taking all prices and level of the stochastic component of the labor-augmenting technical progress as given; (iii) prices $w_{t}, r_{t}$; (v) initial condition on capital $k_{0}$; and (vi) stochastic process (6). Those allocations satisfy the production factor market clearing conditions: $h_{t}^{s}=h_{t}^{D}=h_{t}, k_{t}^{D}=k_{t}$. Formally, the decentralized competitive equilibrium can be defined as a set of sequences $\left\{c_{t}, y_{t}, h_{t}, k_{t}, x_{t}\right\}$ satisfying the system of equilibrium equations (1)-(5), given (6). 


\section{B Decomposing the labor wedge into price and wage markups}

CKM define the labor wedge as a measure of the ratio of the MRS to the MPL:

$$
1-\tau_{h, t}=\frac{m r s_{t}}{m p l_{t}}
$$

Following Galí et al. (2007), we describe how to decompose the labor wedge into price and wage markup components. The price markup, denoted $\mu_{t}^{p}$, is defined as the ratio of the price, $P_{t}$, to the nominal marginal cost of production, $\frac{W_{t}}{m p l_{t}}$, where $W_{t}$ denotes the nominal hourly wage. It can also be expressed as the ratio of the marginal labor productivity, $m p l_{t}$, to the real wage, $w_{t} \equiv \frac{W_{t}}{P_{t}}$. Formally, one gets

$$
\mu_{t}^{p} \equiv \frac{P_{t}}{W_{t} / m p l_{t}}=\frac{m p l_{t}}{w_{t}}
$$

When the price markup increases, the real wage becomes larger than the MPL scaled by the price markup, $w_{t}>\frac{m p l_{t}}{\mu_{t}^{p}}$. Knowing this, firms decide to decrease their demand for labor to make their MPL increase and real wage decrease. By doing so, firms ensure that the equality (11) is again achieved. The wage markup, denoted $\mu_{t}^{w}$, is defined as the ratio of the real wage, $w_{t}$, to the MRS, $m r s_{t}$,

$$
\mu_{t}^{w} \equiv \frac{w_{t}}{m r s_{t}}
$$

When the wage markup increases, the real wage becomes smaller than the MRS scaled upward by the wage markup, $w_{t}<m r s_{t} \mu_{t}^{w}$. Knowing this, households decide to decrease their supply of labor to make their MRS decrease and real wage increase. By doing so, households ensure that the equality (12) is again achieved.

The labor wedge expression in equation (10) can be rewritten as follows,

$$
1-\tau_{h, t}=\frac{m r s_{t}}{w_{t}} \frac{w_{t}}{m p l_{t}}
$$

By combining equations (11), (12) and (13), we obtain an expression linking the labor wedge with the price and wage markups,

$$
\bar{\tau}_{h, t}=\frac{1}{\mu_{t}^{w}} \frac{1}{\mu_{t}^{p}}
$$

where $\bar{\tau}_{h, t}=1-\tau_{h, t}$. Note that the labor wedge is inversely related to both markups. Then, we express equation (14) in its log-linear form,

$$
\tilde{\bar{\tau}}_{h, t}=-\left(1-\tau_{h}\right)\left(\hat{\mu}_{t}^{w}+\hat{\mu}_{t}^{p}\right) \text { with } \hat{\mu}_{t}^{w}=\hat{w}_{t}-m \hat{r} s_{t} \text { and } \hat{\mu}_{t}^{p}=\hat{m p l} l_{t}-\hat{w}_{t}
$$

where $\tilde{\bar{\tau}}_{h, t}=\bar{\tau}_{h, t}-\bar{\tau}_{h}$, and $\hat{s}_{t}=\log s_{t}-\log s, s_{t} \in\left\{\mu_{t}^{p}, \mu_{t}^{w}, m r s_{t}, m p l_{t}, w_{t}\right\}$.

Conditionally to the specifications of the production and utility functions used in the prototype model, the expressions for the MRS and MPL are given by $m r s_{t}=\psi \frac{c_{t}}{1-h_{t}}$ and $m p l_{t}=$ $(1-\theta) \frac{y_{t}}{h_{t}}$, respectively. In log-linear form, the previous equations become $m \hat{r} s_{t}=\hat{c}_{t}+\frac{h}{1-h} \hat{h}_{t}$ and $\hat{m p l} l_{t}=\hat{y}_{t}-\hat{h}_{t}$, respectively. 


\section{References}

Beaudry, Paul, \& Portier, Franck. 2002. The French Depression in the 1930s. Review of Economic Dynamics, 5(1), 73-99.

Bernanke, Ben. 1983. Nonmonetary Effects of the Financial Crisis in the Propagation of the Great Depression. American Economic Review, 73(3), 257-276.

Bernanke, Ben. 1995. The Macroeconomics of the Great Depression: A Comparative Approach. Journal of Money, Credit and Banking, 27(1), 1-28.

Bordo, Michael, Erceg, Christopher, \& Evans, Charles. 2000. Money, Sticky Wages, and the Great Depression. American Economic Review, 90(5), 1447-1463.

Carlstrom, Charles, \& Fuerst, Timothy. 1997. Agency Costs, Net Worth, and Business Fluctuations: A Computable General Equilibrium Analysis. American Economic Review, 87(5), 893-910.

Carré, Jean-Jacques, Dubois, Paul, \& Malinvaud, Edmond. 1972. La croissance française. SEUIL.

Chari, Vadaradajan, Kehoe, Patrick, \& McGrattan, Ellen. 2004. Business Cycle Accounting. NBER Working Paper 10351.

Chari, Vadaradajan, Kehoe, Patrick, \& McGrattan, Ellen. 2007. Business Cycle Accounting. Econometrica, 75(3), 781-836.

Christiano, Lawrence, \& Davis, Jonas. 2006. Two Flaws in Business Cycle Accounting. NBER Working Paper 12647.

Christiano, Lawrence, Motto, Roberto, \& Rostagno, Massimo. 2003. The Great Depression and the Friedman-Schwartz Hypothesis. Journal of Money, Credit and Banking, 35(6), 1119-1198.

Cole, Harold, \& Ohanian, Lee. 2004. New Deal Policies and the Persistence of the Great Depression: A General Equilibrium Analysis. Journal of Political Economy, 112(4), 779-816.

Colton, Joel. 1951. Compulsory Labor Arbitration in France, 1936-1939. King's Crown Press.

Crucini, Mario, \& Kahn, James. 2003. Tariffs and the Great Depression revisited. Staff Reports 172, Federal Reserve Bank of New York.

Eichengreen, Barry, \& Wyplosz, Charles. 1986. The Economic Consequences of the Franc Poincare. NBER Working Paper Series No 2064.

Eichengreen, Bary, \& Sachs, Jeffrey. 1985. Exchange Rates and Economic Recovery in the 1930s. Journal of Economic History, 45(4), 925-946.

Friedman, Milton, \& Schwartz, Anna. 1963. A Monetary History of the United States, 1860-1963. Princeton, NJ: Princeton University Press.

Galí, Jordi, Gertler, Mark, \& López-Salido, David. 2007. Markups, Gaps, and the Welfare Costs of Business Fluctuations. Review of Economic and Statistics, 89(1), 44-59.

Hall, Robert. 1997. Macroeconomic Fluctuations and the Allocation of Time. Journal of Labor Economics, 15(2), S233-S250. 
Hamilton, James. 1994. Time Series Analysis. Princeton University Press.

Harvey, Andrew. 1989. Forecasting, structural time series models and the Kalman filter. Cambridge University Press.

Kersting, Erasmus. 2008. The 1980s recession in the UK: A business cycle accounting perspective. Review of Economic Dynamics, 11(1), 179-191.

Klein, Paul. 2000. Using the generalized Schur form to solve a multivariate linear rational expectations model. Journal of Economic Dynamics \&f Control, 24(1), 1405-1423.

Kobayashi, Keiichiro, \& Inaba, Masaru. 2006. Business Cycle Accounting for the Japanese Economy. Japan and the World Economy, 18(4), 418-440.

Lacoue-Labarthe, Dominique. 2005. La France a-t-elle connu des paniques bancaires inefficientes? Une analyse exploratoire de la crise des années trente. Revue d'économie politique, 115(5), 633-656.

Lama, Ruy. 2011. Accounting for Output Drops in Latin America. Review of Economic Dynam$i c s, \mathbf{1 4}(2), 295-316$.

Mortensen, Dale, \& Pissarides, Christopher. 1994. Job Creation and Job Destruction in the Theory of Unemployment. Review of Economic Studies, 61(3), 397-415.

Mulligan, Casey. 2002. A Century of Labor-Leisure Distortions. NBER Working Paper 8774.

Otsu, Keisuke. 2010. A Neoclassical Analysis of the Asian Crisis: Business Cycle Accounting for a Small Open Economy. The B.E. Journal of Macroeconomics, 10(1).

Pensieroso, Luca. 2011. The Great Depression in Belgium from a Neoclassical Perspective. Review of Economic Dynamics, 14(2), 389-402.

Pissarides, Christopher. 1985. Short-Run Equilibrium Dynamics of Unemployment Vacancies and Real Wages. American Economic Review, 75(4), 676-690.

Prost, Antoine. 2006. Autour du Front Populaire. Seuil.

Saint-Marc, Michelle. 1983. Histoire Monétaire de la France. Presse Universitaire de France.

Sauvy, Alfred. 1984. Histoire Économique de la France entre les deux guerres. Vol. 1-3. Economica. written with the collaboration of Anita Hirsch.

Schnabel, Isabel. 2004. The German Twin Crisis of 1931. Journal of Economic History, 64(3), 822-871.

Schnabel, Isabel. 2009. The role of liquidity and implicit guarantees in the German twin crisis of 1931. Journal of International Money and Finance, 28, 1-25.

Shimer, Robert. 2009. Convergence in Macroeconomics: The Labor Wedge. American Economic Journal: Macroeconomics, American Economic Association, 1(1), 280-297.

Villa, Pierre. 1993. Une Analyse macro-économique de la France au XXème siècle. Paris: Presses du CNRS. 